\title{
The Miniatures and Texts in the E28 Album from the IOM, RAS
}

Abstract: The E28 Album is composed of five stray sheets from an unknown Persian manuscript datable by circumstantial evidence to the 17 th -18 th $\mathrm{cc}$. The texts contained therein are for the most parts accounts pertaining to the activities of the Sufi fraternities in Central Asia in the period from the 11th to the 15th c. The five miniature paintings illustrate the stories told.

Key words: Abu Said Abu-1-Khair, Herat, Khorezm, Amu Darya, sheikhs, mysticism, boat.

An album code-named E28 (inv. No. 10371) is kept in the Arabic-script section of the Department of Manuscripts and Documents of the IOM (Institute of Oriental Manuscripts) of the RAS (Russian Academy of Sciences). It is made up of five stray sheets from a medieval Persian manuscript purchased from an antique shop in Saint-Petersburg on 18 January, 2016. One side of each sheet carries a text accompanied by an illustrating miniature painting (or, conversely, each miniature is explicated by a text), while the other side carries a text only. Incidentally, the miniature with its text can appear both on the obverse and reverse side of the leaf, in which case the illustration-free text and that with a miniature change places. ${ }^{1} \mathrm{~A}$ watchword (custoda) is invariably located below the text on the verso, denoting as it does the end of the narrative and determining the initial word on the recto of the next sheet. Judging by its sporadic pagination, the entire manuscript might have comprised a total of 290 to 300 sheets. On circumstantial evidence (such as the state of paper preservation, the content of the text and the writ-

(C) Kolesnikov Aliy Ivanovich, Institute of Oriental Manuscripts, Russian Academy of Sciences

\footnotetext{
${ }^{1}$ In the present album, this is observable in sheets E28 2 and E28 4.
} 
ing manner), it is datable to the late 17 th or 18 th $\mathrm{c}$. The different pagination markings in pseudo-Arabic, as well as the Arabic figures in the upper right corners of the sheets indicate that the manuscript was already in quires as early as the 20 th c. or the early 21 st.

The scarcity of sources available makes it impossible to make assertions about the content of the manuscript, but even the little that the writer has gleaned from the fragments of its five tales suggests that the genre dealt with was an entertaining story, which was so richly represented in medieval Central Asian literature in the Persian and Tadjik languages. ${ }^{2}$ In the fragments dealt with in this publication, the key role belongs to narratives connected to a greater or lesser extent with the activities of the Sufi sheikhs of the Central Asian area. The main shortcoming of the passages is the absence of the beginnings and endings of the stories recorded on the stray leaves of this small album, but the clarity of the texts in combination with the lifelike quality of the miniatures facilitates understanding the content.

What follows is a description of the material and its characteristics in the same order as the pagination of leaves in the E28 Album.

\section{$\operatorname{E28~1R~(Pl.~1)~}$}

The leaf measures $13 \mathrm{~cm}$ (w. width) $\times 22.3 \mathrm{~cm}$ (h. height).

On the recto a miniature and a text appear inside a frame.

The frame measures $10.8 \mathrm{~cm}(\mathrm{w}.) \times 16 \mathrm{~cm}(\mathrm{~h}$. $) \times 0.4$ (th. thickness).

Figures $11 \mathrm{~V}$ (117) are placed left above the frame and the Latin letter $\mathrm{M}$ appears in the upper right corner of the page.

Most of the space within the frame is occupied by the miniature painting. A group of four conversing men is shown against a blue ground interspersed with a summarily treated plant motif. One of them, in the centre of the composition, asks the others some questions and the three say something in reply. There are three others in the pale pink background (two on the left and one on the right), watching the first group.

A glued-on rectangle over the picture carries four lines of Persian script, the three first ones being lyric distichs (beits or baits), the fourth line a marker in prose indicating transition to a new episode of the narrative. Two more lines are inscribed in a glued-on rectangle in the lower part of the miniature.

\footnotetext{
${ }^{2}$ A catalogue of manuscripts from the RAS, IOM collection that included tales in this genre was compiled in her day by N.N. Tumanovich (TUMANOVICH 1981).
} 


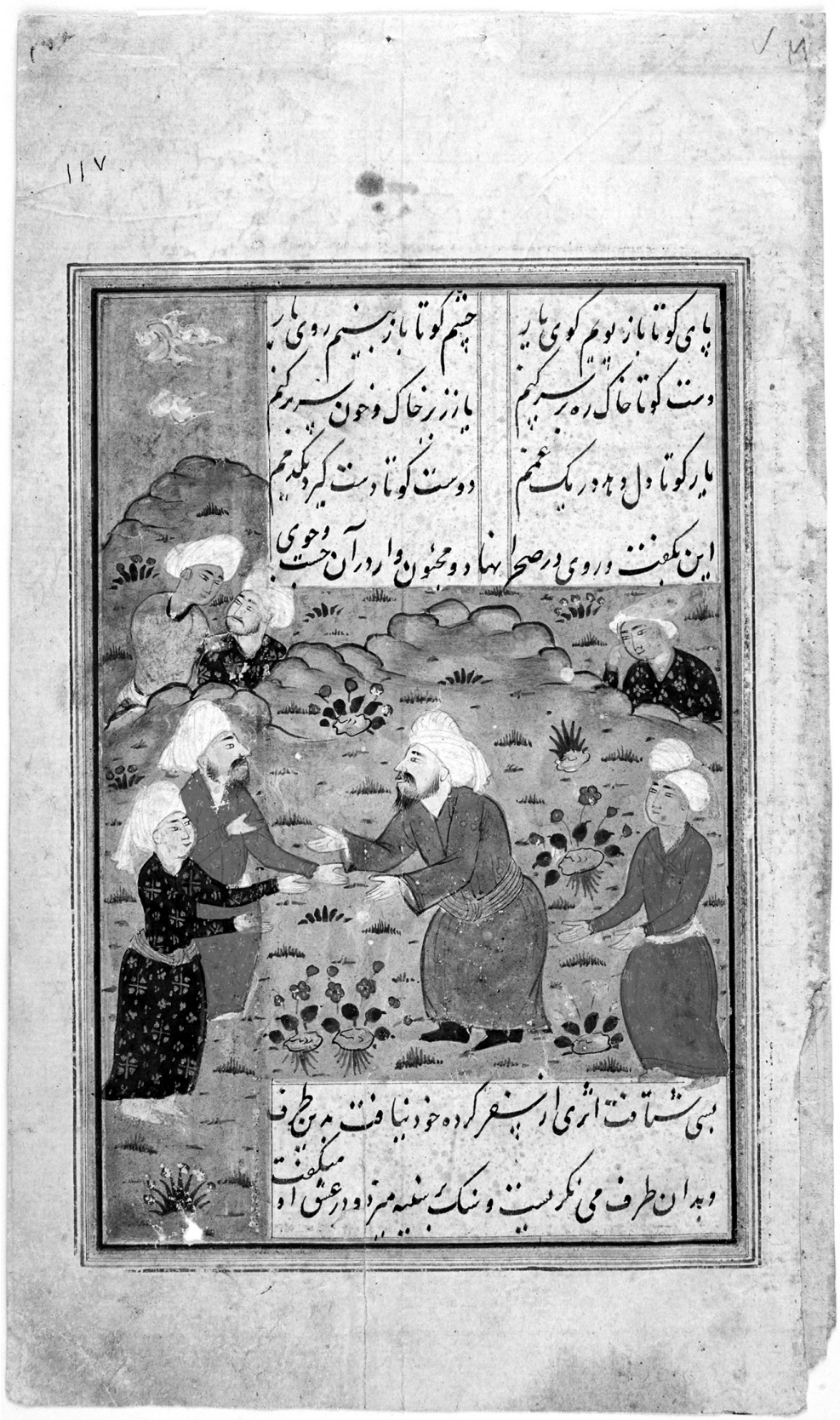

P1. 1: recto of sheet E28 1R 


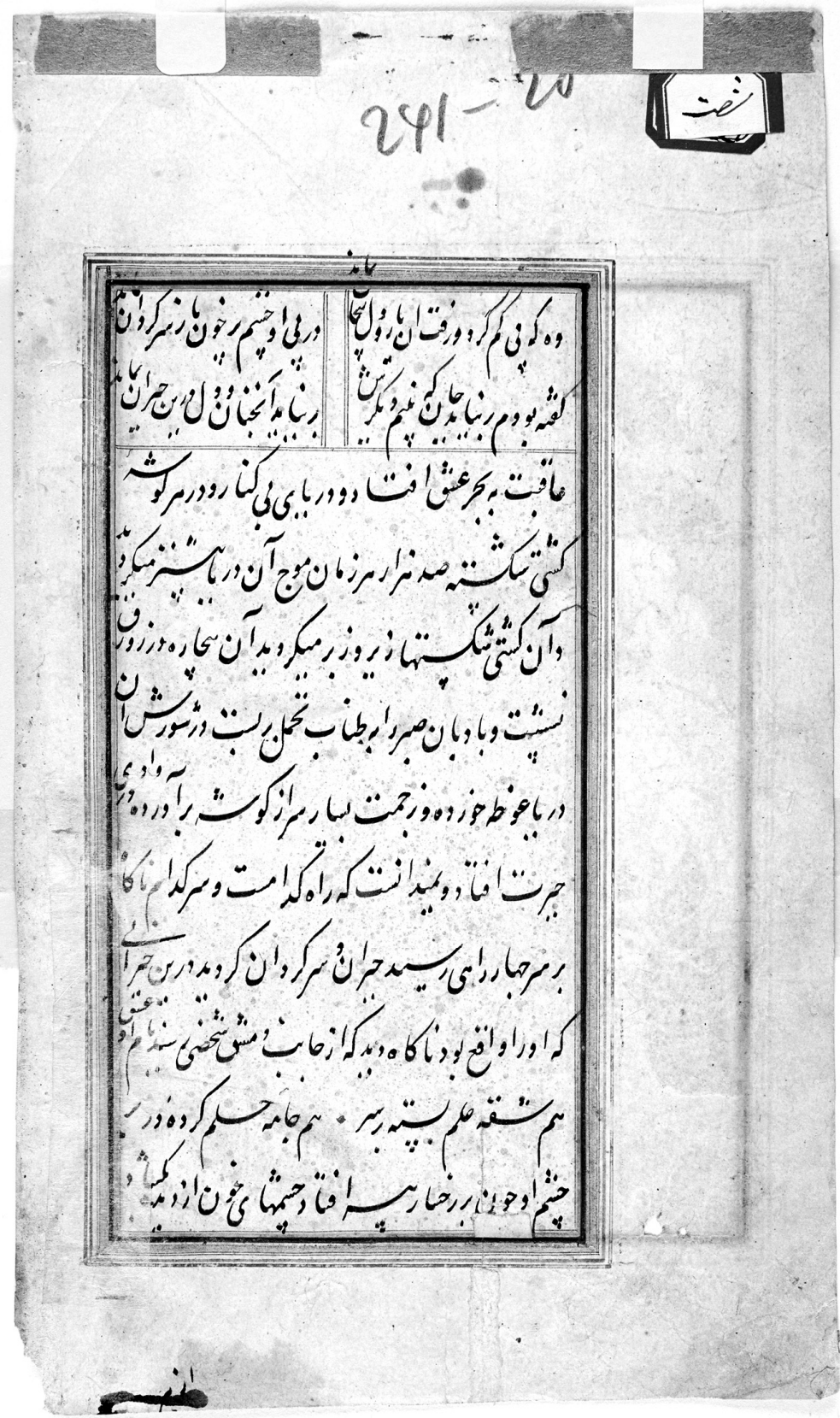

Pl. 2: verso of sheet E28 1V 
Here are the upper texts:

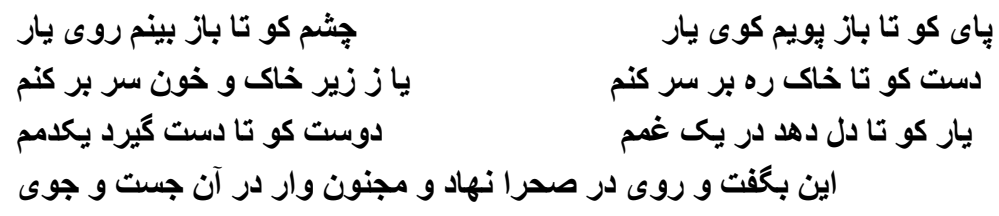

The lower text reads:

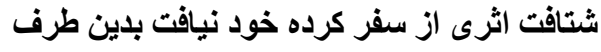

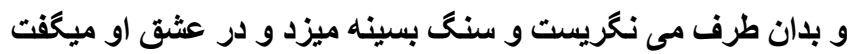

And this is their translation into English:

"Where is that trace to find my friend's street with?

Where is that eye to let me see my friend's face with?

Where is that hand to sprinkle my head with road dust?

Or drag my head out of the blood-soaked earth?

Where is the friend to sympathise with my sorrow?

Where is the beloved one to lend a hand at once?"

Saying that, he made way into the wilderness [desert] and, like Majnun, ${ }^{3}$ began a search [for his friend].

Hard as he searched, he found no trace of his friend on his sojourn. He would now peer in one direction, then in the other, and would pound himself on the chest with a rock, repeating in romantic despair.

\section{E28 1V (Pl. 2)}

The reverse side contains a text within a frame and a watchword below it.

The frame measures $8.3 \mathrm{~cm}(\mathrm{w}.) \times 16 \mathrm{~cm}(\mathrm{~h}.) \times 0.5 \mathrm{~cm}$ (th.).

Inscribed in the upper right of the page, is the number 60 in words (شست), within a smaller later-date polychrome frame; next to it appears a pencil mark: 241-20.

\footnotetext{
${ }^{3}$ Hero of Layli and Majnun, a poem by Nizami Ganjavi (1141-1209).
} 
Confined within the frame are 12 lines of Persian text in the Nastaliq hand, ${ }^{4}$ two of which make, in terms of content, a romantic ruba $i$ quatrain, whereas the other ten describe the hero's adventures in his quest of the person he deified.

The texts are as follows:

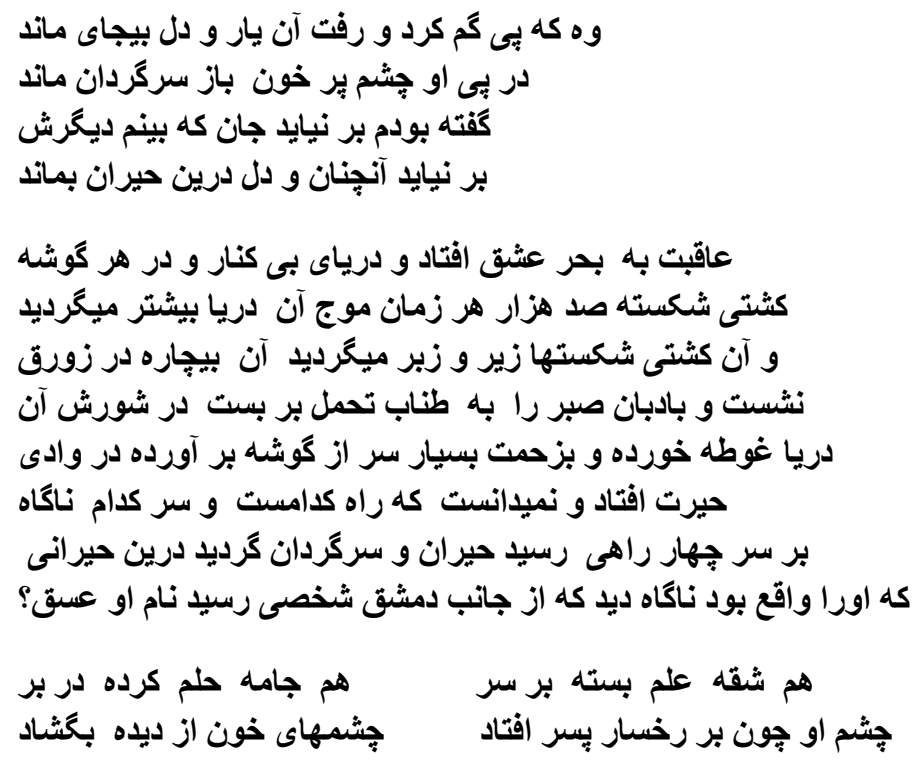

Their translations into English are as follows:

[Ruba'i]:

"Crying shame every trace has been lost. My friend missing, my heart's ever restless.

Searching for him, I suffer again no end, weeping torrents of bitterest tears.

I was right when I said he would never come back t' let me see him again even briefly.

As he fails to return, my forlorn broken heart is in sorrow plunged and despair.

${ }^{4}$ One of the four main hands in Arabic calligraphy, which combines the stateliness of Naskh and roundness of Ta'liq. It became established in Iran in the 14th c. For varieties of this hand and its creators see: YUSOFI 1990, 696-699 and 709-714; Qazi Ahmad (AKIMUSHKIN) 2016, 162-174. 
[Narrative]:

That way he drowned himself in the sea of love. Meanwhile the boundless sea around him kept breaking the ship (keštī). Every time hundreds of thousands sea waves grew more powerful, scattering the fragments of the vessel all over the sea surface. The seafarer went over into a zawraq boat, fastening its sail of patience with a rope of endurance. In the middle of the stormy sea, he suddenly plummeted into an abyss and only with great difficulty was able to surface from the depth. Suddenly he found himself in a wonderful valley and could not see where it led or where terminated. Unexpectedly, he reached an intersection of four roads and halted in great amazement and confusion. Lingering in that state, he saw somebody named Love $^{5}$ making a sudden appearance from the direction of Damascus.

[Distichs]:

Wearing the same headband of scholarship,

The same aura of modesty round his head.

When his eye fell on the young man's face,

Hot tears streamed down his cheeks.

Clearly discernible near the bottom left edge of the page is this watchword: از از (“from every/each...).

Comment: The beginning and end of the narrative are missing, yet the purport is not hard to perceive: the passage is about the mystic Sufi love by the worshipper for God as supreme object of veneration. In Sufi literature, the boat the dervish takes implies estrangement from daily life needs and concerns, i.e. asceticism. ${ }^{6}$

\section{E28 2V (P1. 3)}

The sheet measures $12.8 \mathrm{~cm}$ (w. top) and $13 \mathrm{~cm}$ (w. bottom) $\times 22 \mathrm{~cm}$ (h.). The recto carries a text inside a frame.

The frame measures $8.2 \mathrm{~cm}$ (w. bottom) and $8.1 \mathrm{~cm}$ (w. top) $\times 15.7-$ $15.8 \mathrm{~cm}$ (h.) $\times 0.4 \mathrm{~cm}$ (th.).

\footnotetext{
${ }^{5}$ The text erroneously has عشت in lieu of عشت .

${ }^{6}$ For more details on mystic love see: BARTHOLd 1966, 114-120; BerTels 1965, 181184; SCHIMMEL 2012, 138-156.
} 
No Persian pagination appears in the upper left corner of the sheet. The upper margin over the frame is inscribed with Figures 241-16 in pencil and 09.20 in ink.

The space within the frame is inscribed in the Nasta liq hand with 12 lines of Persian text.

The text follows.

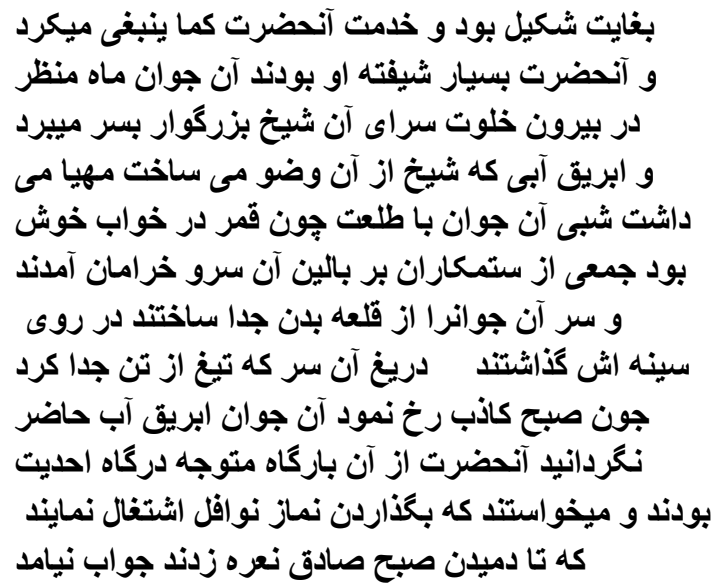

This is its translation into English:

...He was very well-built and served His Holiness properly. And His Holiness was literally enchanted by the moonfaced young man that lived behind the solitary cell occupied by the great sheikh. The youth would usually prepare a jug of water the sheikh made ablutions with. One night, when the handsome moonfaced youngster enjoyed his sleep, some villains stole to the pillow where that graceful cypress of a man lay, severed his head and laid it on his chest:

I feel so much pity for that head the sword cruelly severed from its body!

When the dawn cracked (lit. "revealed its face"), the youth had not delivered his jug of water. His Holiness made way from his cell to the secluded worship place and wanted to have optional prayers (namāz-e nawāfel) ${ }^{7}$ first. He went on calling for the [servant] until daybreak [lit. until morning proper], but the call went unanswered.

7 "Optional" is used here for prayers that supplemented obligatory ones that lay worshippers said. It cannot be ruled out, however, that in this particular context hadīs an-nawäfil was implied, which promised the presence of God in loving slaves for their pious deeds (SCHIMMEL 2012, 276, 496). 


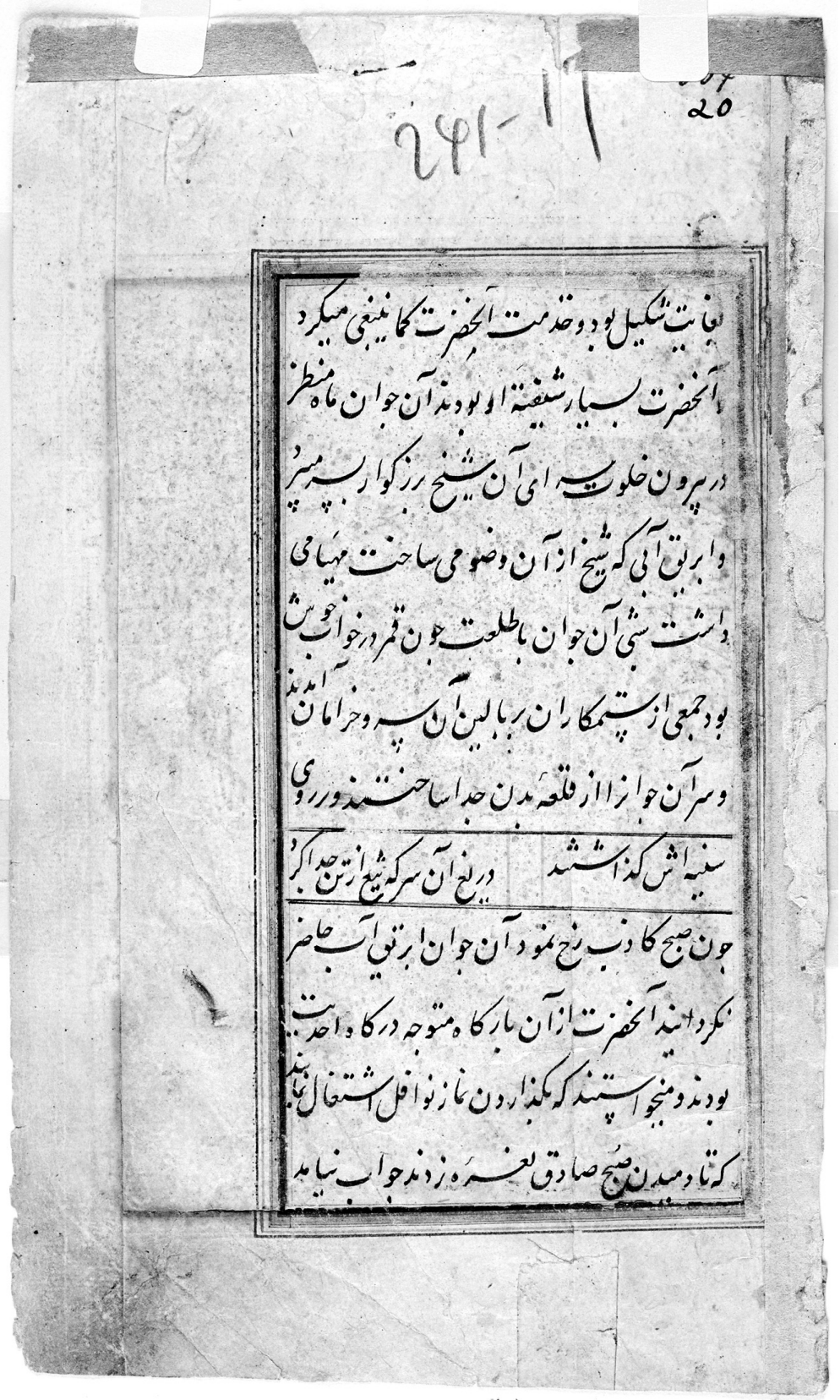

Pl. 3: recto of sheet E28 $2 \mathrm{~V}$ 


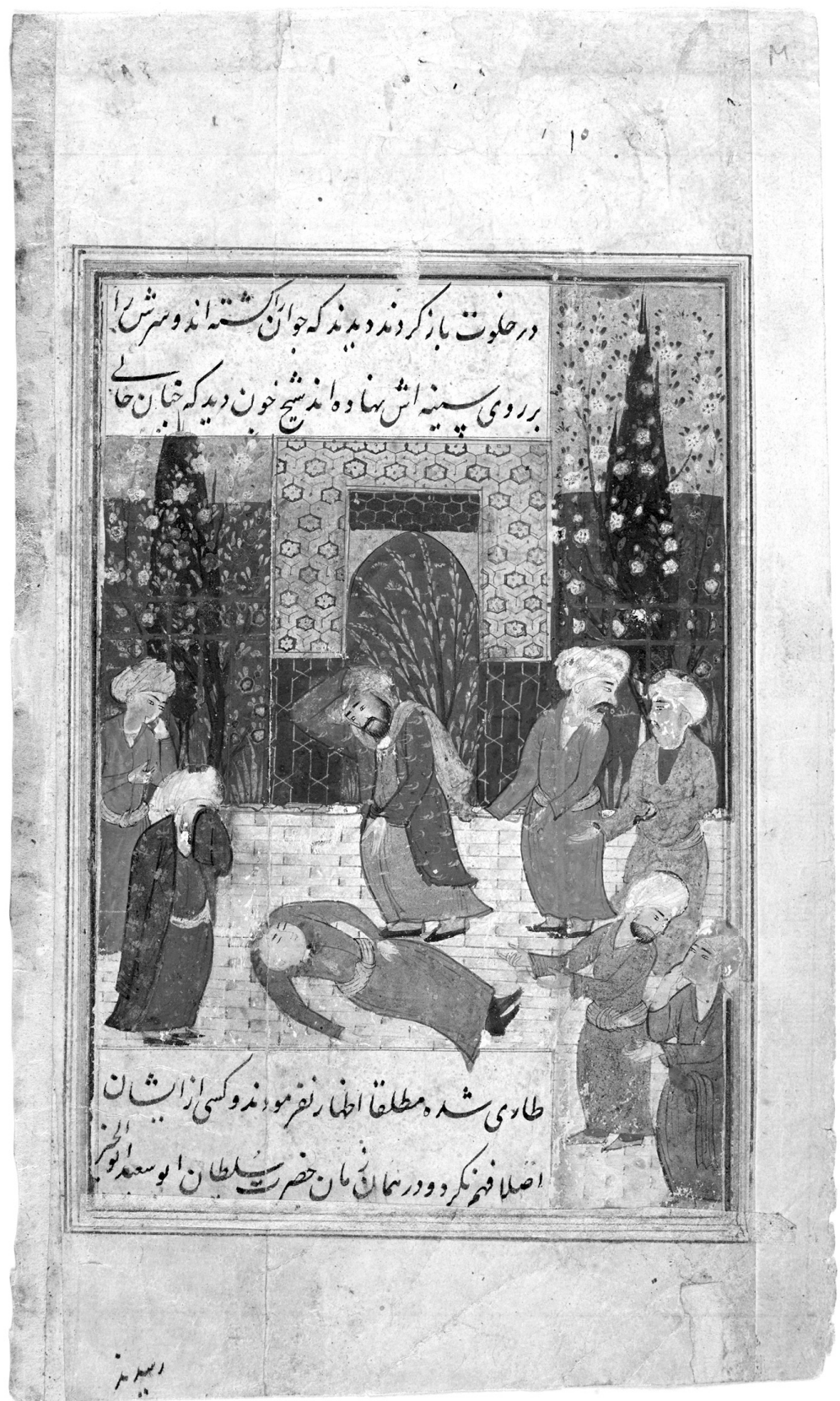

P1. 4: verso of sheet E28 2R 


\section{$\operatorname{E28~2R~(P1.~4)~}$}

The reverse side carries a miniature with a text within a frame, a watchword below the latter.

The frame measures $11 \mathrm{~cm}$ (w. bottom) and $10.8 \mathrm{~cm}$ (w. top) $\times 15.8 \mathrm{~cm}$ (h.) $\times 0.4 \mathrm{~cm}$ (th.).

The upper left corner, above the frame, is inscribed with a washed-out number, $Y \wedge \leq(284)$, with another number, 10 (15), and with the Latin capital letter $\mathrm{M}$ in the extreme right corner.

The miniature depicts the aftermath of the murder: seven men stand round the beheaded body appalled by the horrific crime. Two glued-on lines of text continuing the narrative appear right under the upper edge of the frame.

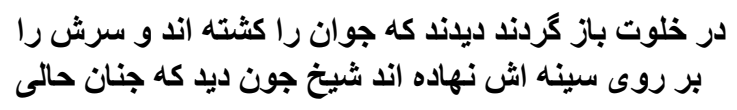

Here is the English for them:

"People gathered in the cell and saw the youth had been killed and his head had been laid on his chest. When He (the sheikh) saw that something unexpected..."

In the bottom part of the frame, under the picture, the two last lines of the text appear. Here they are:

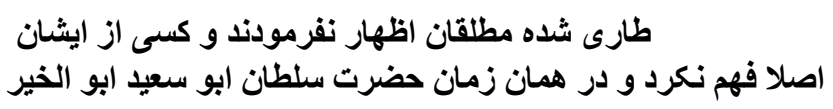

Their translation into English is as follows:

"...had happened, He [the sheikh] said nothing at all. None of them [none of those present] understood anything. Immediately His Majesty Sultan Abu Said Abu-1-Khair [arrived].

Comment: The person referred to is Abu Said Abi-1-Khair Maikhani (967-1049), one of the founders of the Eastern (Khorasan) school of mysticism and the head of the Sufi centre in Nishapur, (RYPKA 1959, 216-217; BERTELS 1965, 47-50; BÖWERING 1983, 377-380; O.A. 1991, 10-11; SCHIMMEL 2012, 243).

A watchword, رسيدند ("arrived"), appears under the frame near the lower left edge of the page. 


\section{$\operatorname{E28~3R~(Pl.~5)~}$}

The sheet measures $13.5 \mathrm{~cm}$ and $13.4 \mathrm{~cm}(\mathrm{w}.) \times 22 \mathrm{~cm}(\mathrm{~h}$.).

The recto is occupied by a miniature and a framed text inscribed in rectangles glued onto the image.

The frame measures $11.4 \mathrm{~cm}(\mathrm{w}.) \times 15.8 \mathrm{~cm}(\mathrm{~h}$. $) \times 0.4 \mathrm{~cm}$ (th.).

Arabic numbers, $\Delta 4$ (56) and ${ }^{4} \cdot(60)$, appear on the left above the frame.

The upper right corner of the sheet is inscribed in ink with an Arabic number, $\vee \vee(77)$, and the Greek letter delta $(\delta)$.

Inside the frame there is a miniature depicting a drunk attacking a sheikh and breaking his head with a musical instrument. The four witnesses shown condemn the pugilist.

The text over the miniature (4 lines) opens with a short poetic maxim on the advantages of voluntary privations and hardships for the sake of attaining the ultimate goal of unity with God, illustrating the dicta with examples from the sheikh's pious life. Another text (2 lines), under the miniature, records the fact of the bodily damage sustained by the sheikh.

Here is the text appearing over the miniature:

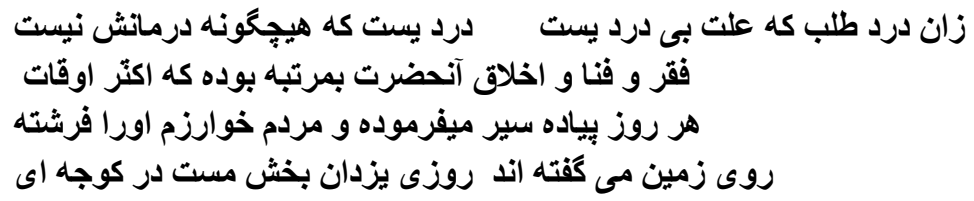

Translations into English follow.

This is the distich in English:

"Summon pain that rids of pain [lit. "is the cause of pain's absence"],

That pain for which no remedy exists".

The self-imposed poverty, asceticism and piety of His Holiness reached a degree enabling the man to spend most of his time walking on foot daily and the residents of Khorezm would call him a terrestrial angel. One day in a street in that city a drunkard named Yazdanbakhsh...

This is the text appearing under the miniature:

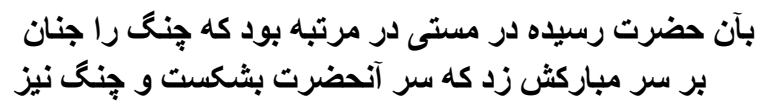




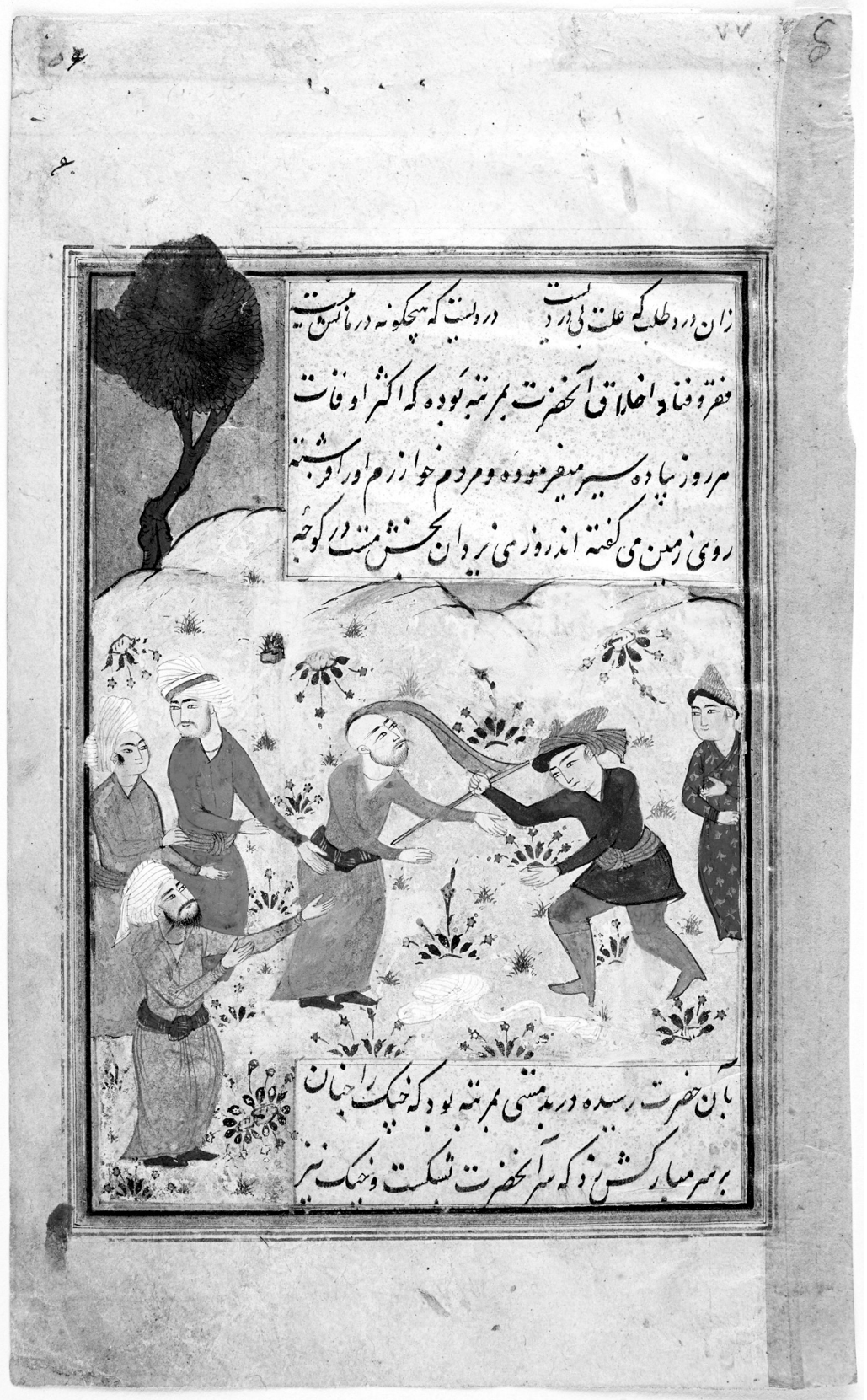

Pl. 5: recto of sheet E28 3R 


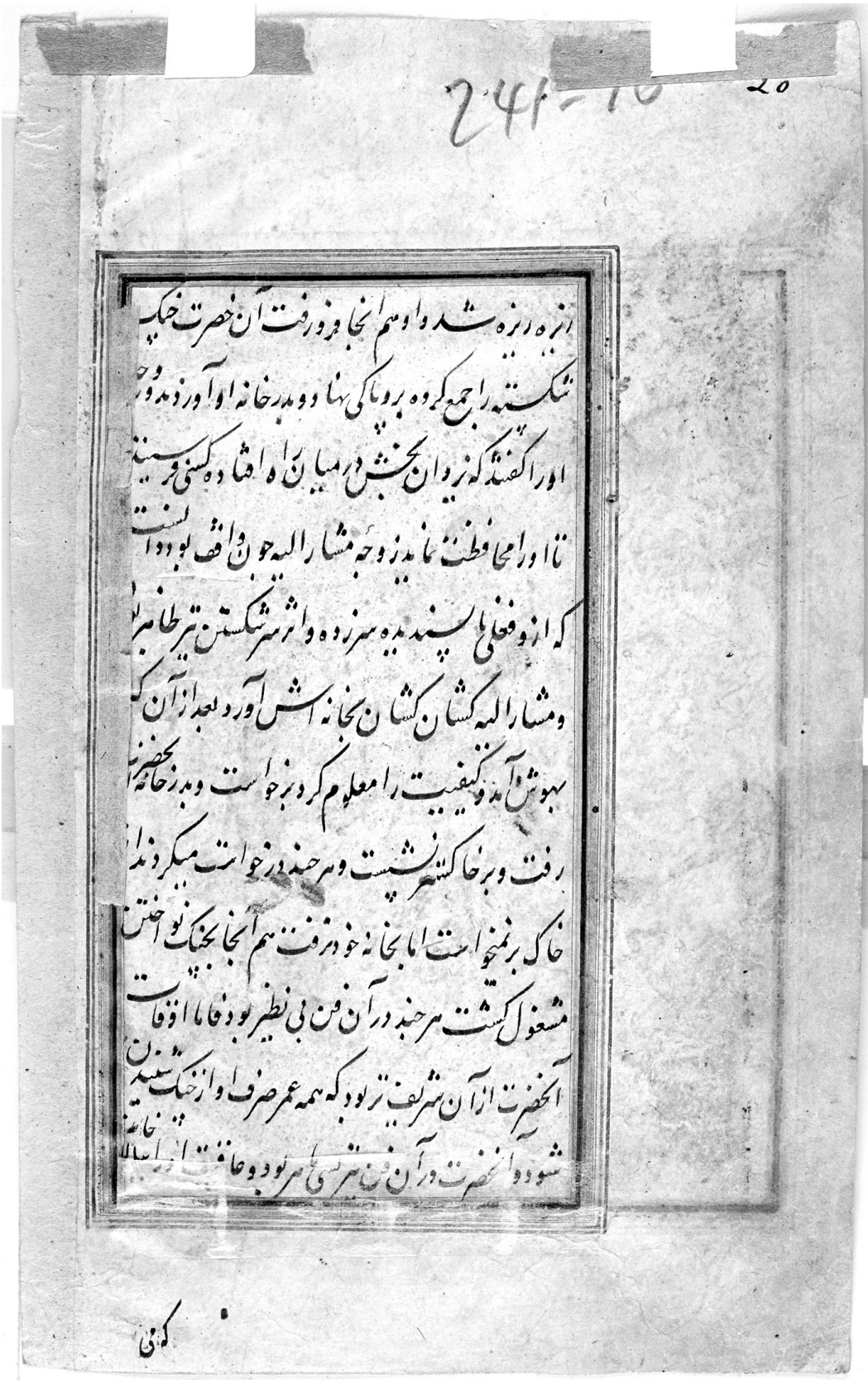

P1. 6: verso of sheet E28 3V 
And this is the English for it:

...came up to His Holiness. The fellow was so drunk and he hit His Holiness' blessed head so hard with a chang $^{8}$ that His Holiness's head was broken. And so was the chang..."

\section{E28 3V (P1. 6)}

The verso contains a text within a frame and a watchword below the frame.

The sheet measures 8.4 and $8.3 \mathrm{~cm}(\mathrm{w}) \times$.15.8 and $15.9 \mathrm{~cm}(\mathrm{~h}.) \times 0.4 \mathrm{~cm}$ (th.).

Above the frame runs a later-date pencil note: $241-70 ; 20$, in ink, is in the top right corner.

Within the frame appear 12 lines of Persian text in the Nasta'liq hand, which continue the narrative.

This is the Persian text:

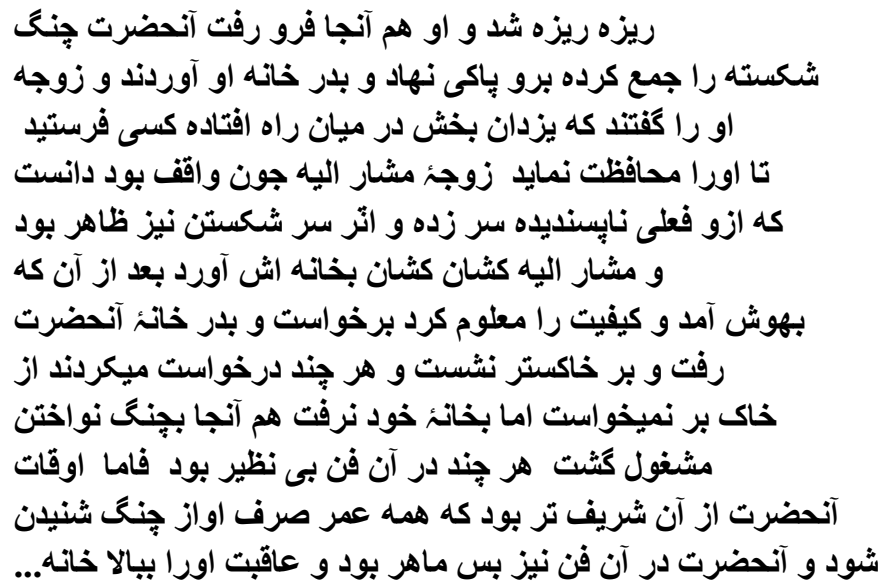

${ }^{8}$ Chang is a variety of the harp (GAFFAROv 1976, I, 239). The article in the Encyclopedic Persian Dictionary is hardly more exhaustive, but the drawing next to the text shows beyond doubt that it is a harp of sorts (MUHAMMAD HUSAYN TABRIZI (MU'IN) 1963, 664). The miniature itself depicted the two surviving facets of the broken instrument. The chang in action can be seen in a miniature in the hand-written copy of Nizami Ganjavi's Hamce manuscript dated 1431. It shows a hunt by Bahram Gur and his beloved Fitne strunging the chang (ADAMOVA 2010, 142-143, pl. 28). The difference of the Oriental chang from the European harp is the smaller size of the former. 
Its translation into English follows:

...smashed into smithereens. The man himself [the assailant] fell down next to it. His Holiness gathered the broken chang, cleaned and took it to the man's house. He said to his wife, "Yazdanbakhsh has had a fall and lies on the road. Send somebody to guard him." When the aforementioned man's wife heard what was up, she realized something vicious had been done, as was evident also from the wound on the head [of His Holiness]. The woman dragged the aforementioned husband to their home. After he [Yazdanbakhsh] came to [lit. "after regaining consciousness"] and appraised the circumstances, he got up and went to the doorstep of His Holiness. In front of the entrance he sat down on the ground [lit. "on the ashes"] and would not stand up no matter how much they asked him to; nor did he go back home. At last he began playing the chang. As he [Yazdanbakhsh] was unequalled in this art, the mood of His Holiness grew increasingly high-minded, willing to listen to the sound of the chang all his life as it were. His Holiness, too, was well versed in this art. Finally, he [invited] the musician into his room upstairs..."

A watchword appears near the bottom left edge of the sheet: كه مى ("in order to...").

\section{E28 4V (P1. 7)}

The sheet measures 13.5 and $13.6 \mathrm{~cm}(\mathrm{w}.) \times 22 \mathrm{~cm}(\mathrm{~h}$.).

The recto only contains texts within a frame.

The frame measures $8.3 / 8.4 \mathrm{~cm}(\mathrm{w}.) \times 16 \mathrm{~cm}(\mathrm{~h}.) \times 0.4 \mathrm{~cm}$ (th.).

In the top left corner two numbers in ink, 764 and 20, appear inside a small polychrome frame.

A pencil mark, 241-10, appears in the upper central part.

The margin next to the left side of the frame is inscribed with an Arab number, $\Delta \leqslant$ (54), which probably denotes the ordinal number of the story in the manuscript. Inscribed inside the frame in the Nasta'liq hand are 12 lines of Persian text providing the ending of one story and the beginning of the next one. 


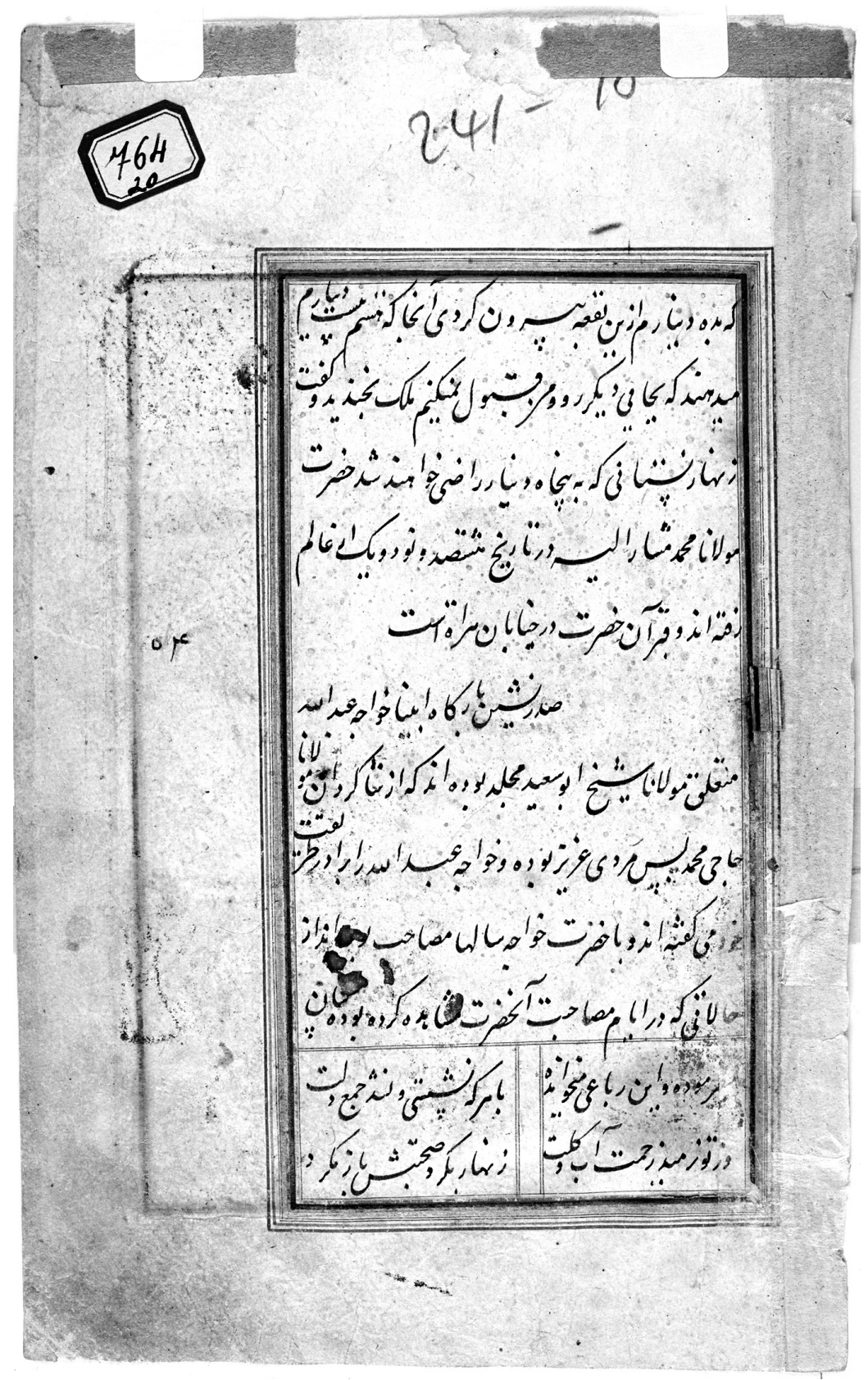

P1. 7: recto of sheet E28 4V 


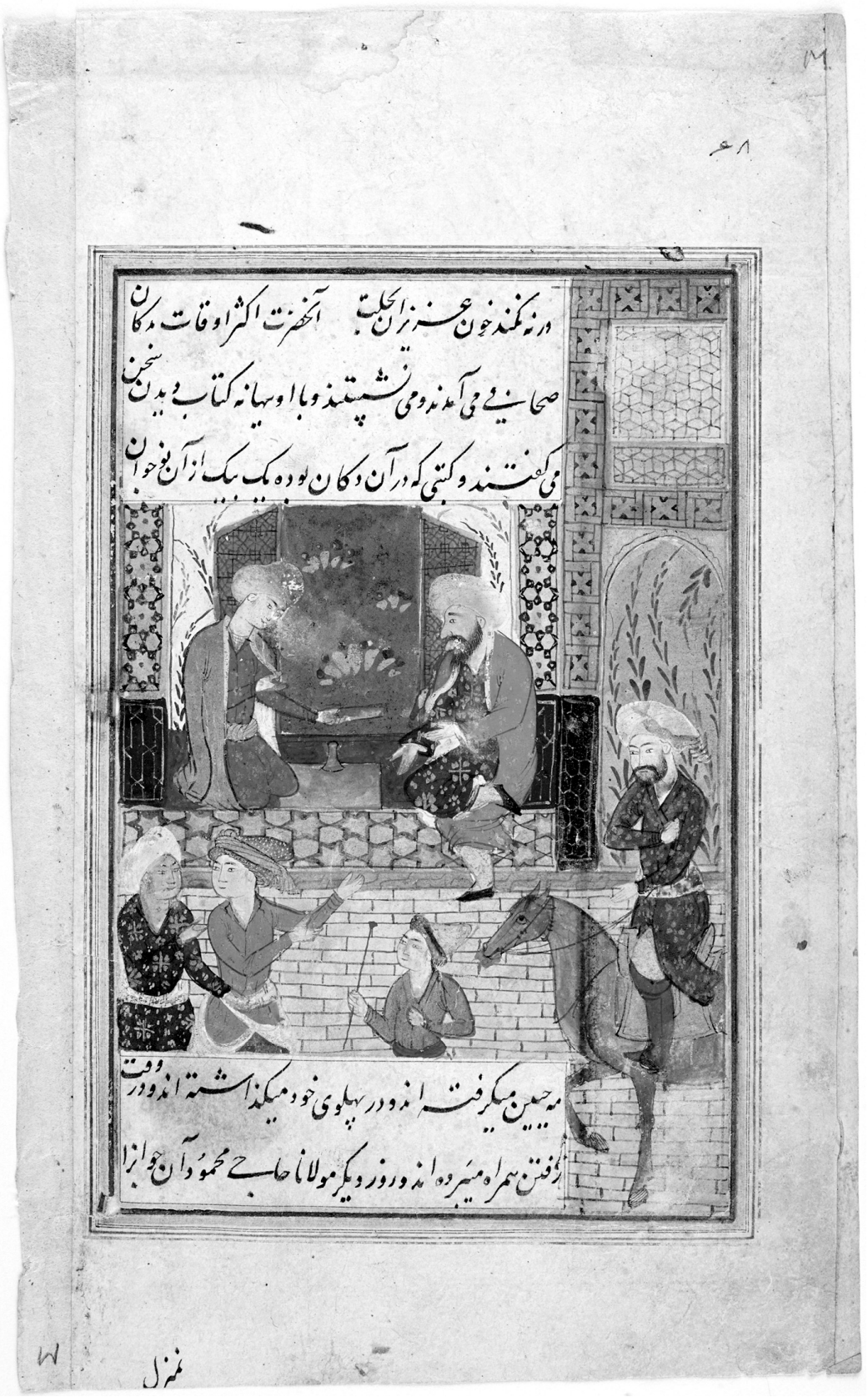

Pl. 8: verso of sheet E28 4R 
This is the Persian text:

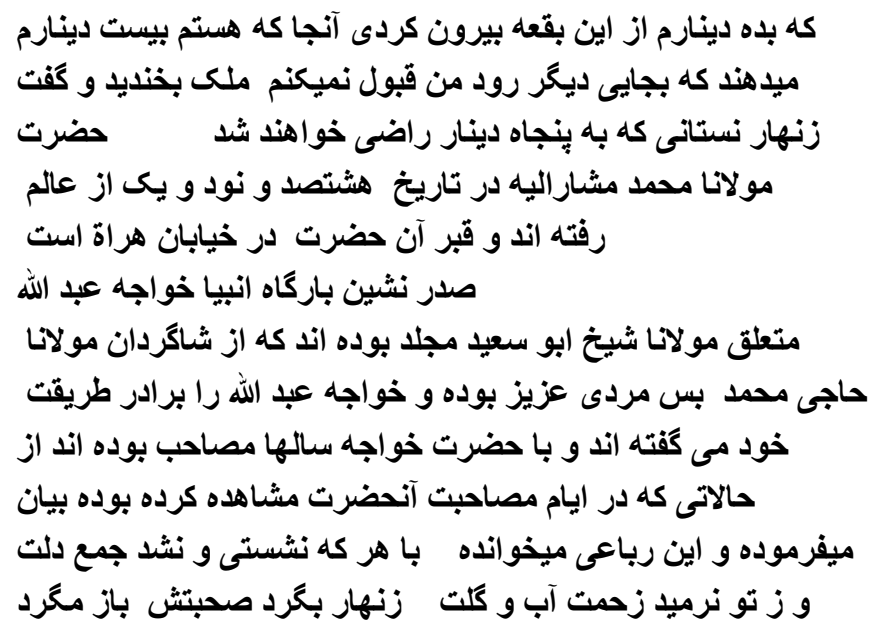

Its translation into English follows:

For those ten dinars of mine that you earned from this abode [version: "plot of land"] I will be given twenty dinars where I live. If it goes elsewhere, I will disagree [lit. will not accept that]. The Shah laughed and said: "No need to apologize, they will agree for fifty dinars".

Their Holiness, our aforementioned Lord Muhammad departed from this world in $891 \mathrm{AH}$ (1486 AD). The grave of Their Holiness is in an avenue/alley of Herat.

54 Khoja Abdallah, the head of Prophets' Hall, a relative of our Lord Abu Said, in his days of working as a bookbinder, used to be one of the most favourite disciples of our Lord Hajji Muhammad, who called Hajji Abtallah his spiritual brother in tariqat (the mystic way to truth comprehension). For years he was an interlocutor of His Holiness Khoja [Abdallah]. ${ }^{9}$ Of the mystic fervour that he witnessed on the occasions of his communion with His Holiness, [Hajji Muhammad] would often reminisce, citing the following quatrain:

"Beware of each one you have talked with [lit. "sat with"] and your heart

Not turning more attentive [lit. "not concentrating", "not getting composed"] for that talk.

\footnotetext{
${ }^{9}$ Judging by the mention of kinship between Khoja Abdallah and Abu Said Maikhani, the episodes took place in the 11 th $\mathrm{c}$.
} 
Nor did you feel any concern as a result — about your nature/ego.

Beware then, and don't restart conversing/debating with them any longer.

\section{E28 4R (P1. 8)}

The verso includes a miniature and a text (inside a frame), with a watchword below. The frame measures $10.8 / 10.9 \mathrm{~cm}$ (w.) $\times 16 \mathrm{~cm}(\mathrm{~h}.) \times 0.4 \mathrm{~cm}$ (th.).

A number in ink, $9 \wedge$ (68), appears on the right above the frame; the upper right corner is inscribed with the Latin $\mathrm{M}$ in pencil.

Two thirds of the space within the frame is occupied by the miniature, which depicts a young man in a bookbinding workshop, who hands a book to a Shaikh. In front of the shop stand two passers-by, talking, a mounted horseman and a young man wearing a turban, with a cane in his hand. Over the miniature run three lines of Persian text, continuing the narrative; two concluding lines appear under the miniature.

Here is the original text:

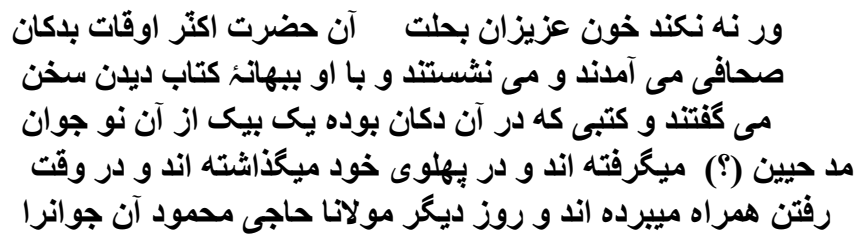

Its translation follows:

Associate otherwise your Saints ${ }^{10}$ blood won't forgive your.

His Holiness spent most of the time in the bookbinding shop, where he sat and talked with the young craftsmen under the pretext of choosing books. One by one, the books from the shop were picked up from the friendly young man and stocked near the guest's seat, to be taken away when leaving. The next day His Holiness Hajji Mahmud [invited] the young man [to his home].

A watchword, منزل ("home"), appears near the lower left edge of the page.

${ }^{10}$ GAFFAROV, 1976, II, 557. 


\section{$\operatorname{E28~5R~(P1.~9)~}$}

The sheet measures $13.6 \mathrm{~cm}(\mathrm{w}.) \times 22 \mathrm{~cm}(\mathrm{~h}$.).

The recto contains a miniature and a text (inside a frame).

The frame measures $11.3 \mathrm{~cm}(\mathrm{w}.) \times 16 \mathrm{~cm}(\mathrm{~h}.) \times 0.4 \mathrm{~cm}$ (th.).

The upper left corner, outside the frame, is inscribed in gouache with 2 figures: I $r v$ (137) and, slightly lower, $\Delta r$ (53). The upper number pertains to general pagination, the lower one may indicate the ordinal number of the narrative.

The miniature depicts a wrestling scene, the outcome of which is keenly watched by a mounted horseman and by seven unmounted men. Inscribed over the miniature are six lines of Persian text in the Nasta 'liq hand, one line appearing under the miniature.

Here is the text in the Persian original:

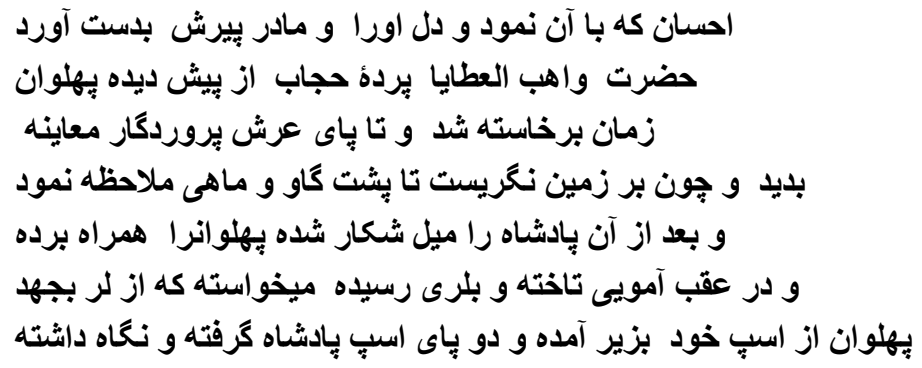

Its translation into English is as follows:

By virtue of magnanimity [towards the defeated fighter] he captivated his heart and the heart of his elderly mother. His Majesty, who had brought lavish presents, was hiding behind the curtain. The knight Zaman stood up and eyed everything up to the Creator's Throne. And when he looked at the ground, he took note of the cattle and fish. Then the padishah fancied a hunt, and he took along the knight with him. They galloped to the other side of Amu Darya and reached a canal. The padishah was about to jump over the canal. However, the knight dismounted from his horse, lifted [lit. "took"] the padishah's horse by two legs and held it like that. 
E28 5V (P1. 10)

The verso carries a text (within a frame) and a watchword.

The frame measures $8.5 / 8.2 \mathrm{~cm}(\mathrm{w}.) \times 16 \mathrm{~cm}(\mathrm{~h}$. $) \times 0.4 \mathrm{~cm}$ (th.).

Inside the frame appear three lines of Persian prose text in the Nasta'liq hand and nine lines of distichs.

Here are the Persian texts:

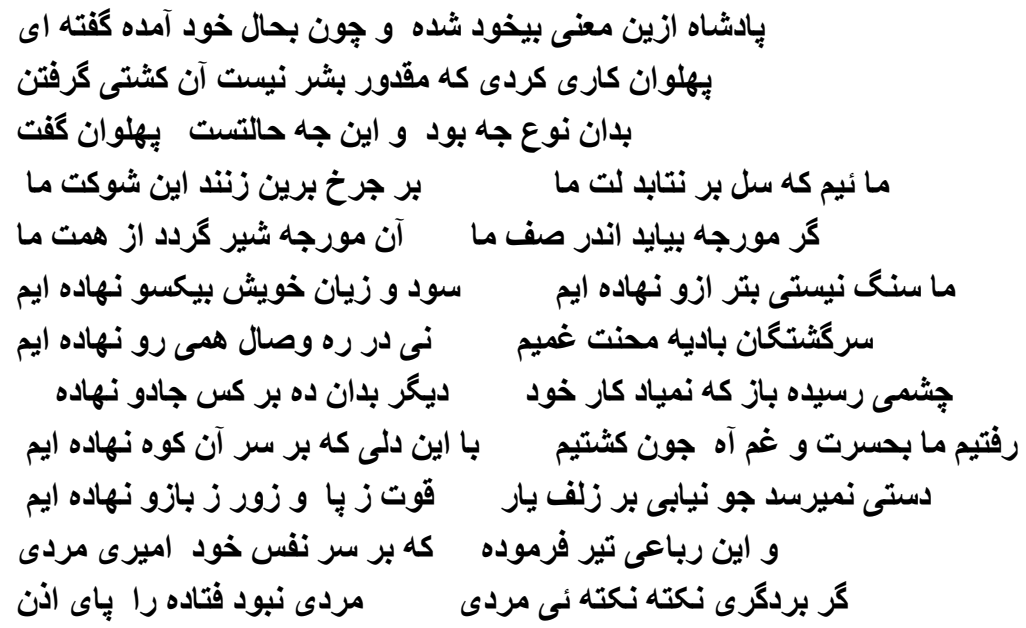

Their translations into English follow:

All that literally made the padishah faint. When he came to, he said to the hero, "Hey, giant! What you have accomplished is beyond human ability. The way you wrestled, and what you have done this time." The knight replied:

"We are those whose vessel/raft $(s a l)^{11}$ will not turn into our wreckage, Our gallantry looms heaven-high.

If an ant should join our ranks,

Our grace will convert the tiny thing into a lion.

We laid the stone of non-existence worse than the ant did, We have placed our benefits and harm on the same side.

We are wanderers in the wilderness of worry and sorrow, Our eyes not fixed on the path of communion [with God].

\footnotetext{
${ }^{11}$ GafFarov 1976, II, 469.
} 


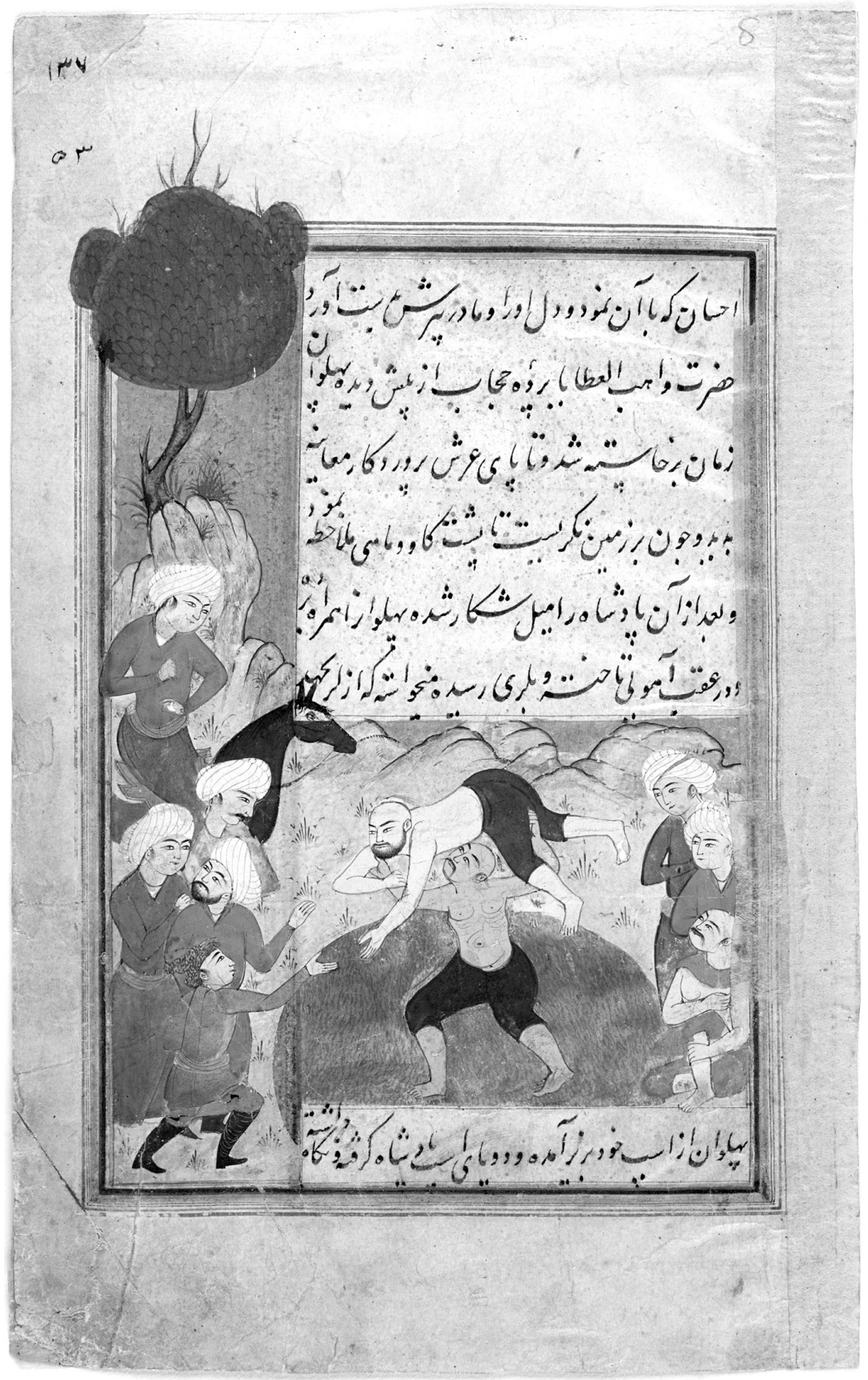

P1. 9: recto of sheet E28 5R 


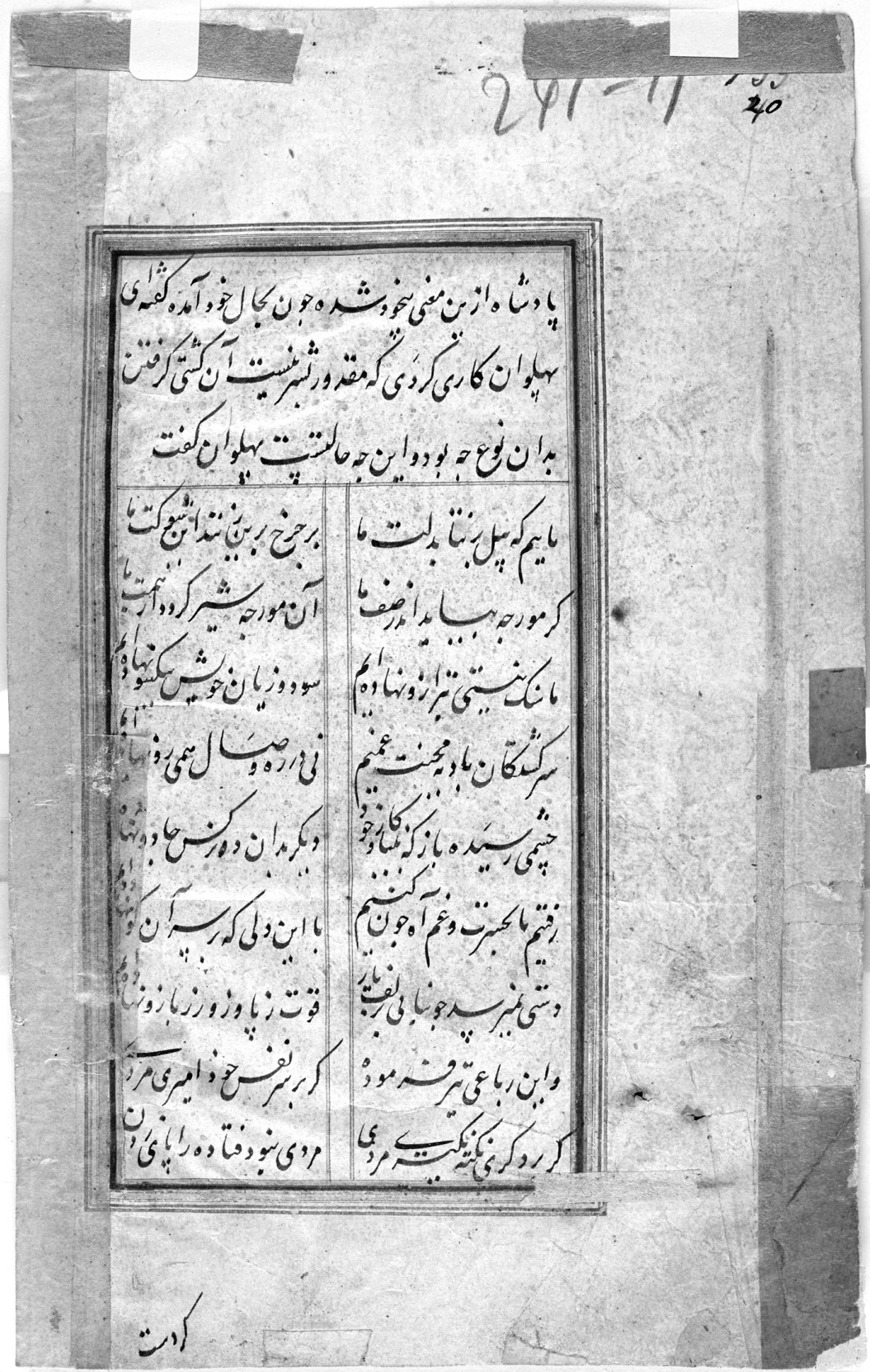

Pl. 10: verso of sheet E26 5V 
He who suffered from the evil eye will not return to his pastime.

For he had handed over his calling to the abode of the wizard.

We went in gloom and great sorrow as we wandered,

With our heart left behind on the peak of that mountain.

Happiness will become unattainable unless you find a friend in a lock of hair.

We have contributed to this end the strength of our legs and the might of our hands".

Besides, he exptemporised (lit. "shot forth") this quatrain (ruba i $i)$ :

"He who manages his passions is a real man.

He who rules over the others is a middling man.

A man will never ask permission from a defeated one..."

The fourth line is missing. It might have been carried over to the sheet that followed, as indicated by the watchword, كردست (If the hand...).

\section{References}

ADAmova Adel 2010: Persidskie rukopisi, zhivopis' i risunok XV-nachala XX veka. Kata$\log$ kollektsii [Persian manuscripts, paintings and drawings of the 15th - early 20th cc. Catalogue of the collections]. St. Petersburg: The State Hermitage Publishers.

Barthold Vasiliy V. 1966: Akademik V.V. Bartol'd. Sochineniia. T. VI: Raboty po istorii islama i Arabskogo khalifata [Collected works, vol. VI: The Works on the history of Islam and on the Arab Kaliphate]. Moscow: Nauka.

BERTEL's Yevgeniy E. 1965: Sufizm i cufiiskaia literatura [Sufism and Sufi Literature]. Moscow: Nauka.

Böwering G. 1983: “Abū Sa‘̄id Fażlallāh b. Ab̄̄’l-Kayr”. In: Encyclopaedia Iranica, ed. by E. Yarshater, vol. I, fasc. 4. London, Boston, Melbourne and Henley: Routledge \& Kegan Paul, 377-380.

Gaffarov M.A. 1976: Persidsko-Russkii slovar' [The Persian-Russian dictionary in 2 volums. Vol. I, ed. by F.Ye. Korsh, vol. II, ed. by L.I. Zhirkov]. Moscow: Nauka.

Mohammad HosAyn eBN-E Khalaf DE TABRiz 1963: Borhān-e Qāte '... Edition entièrement revue... par Moh. Mo‘īn, vol. 2. Teheran: Ebn-e Sīnā éditeur, 664-665.

O.A. (AKIMUSHKIN Oleg F.) 1991: “Abu Sa‘id Maykhani”. In: Islam. Encyclopedicheskii slovar' [Islam. Encyclopaedical dictionary]. Moscow: Nauka.

QAZI AHMAD BIN HUSAYN AL-HUSAYNI QUMI 2016: Traktat o kalligrafakh i khudozhnikakh (Kriticheskii tekst pervoi redaktsii na baze trekh spiskov, perevod na russkii iazyk, prilozheniia, kommentarii i primechaniia O.F. Akimushkina; podgotovka k publikatsii, predis- 
lovie i ukazateli B.V. Norika) [Tract on Calligraphers and Painters (critical text on the basis of the 1st ed. of three manuscripts, translated into Russian, with supplements, comment. and footnotes by O.F. Akimushkin; prepared for publication, prefaced and indexed by B.V. Norik. Moscow: Sadra.

RYPKA, J. 1959: Iranische Literaturgeschichte. Unter Mitarbeit von O. Klima, V. Kubičkova, J. Bečka, J. Ceipek, I. Hrbek. Leipzig: VEB Otto Harrassowitz.

Schimmel, A. 2012: Mir islamskogo mistitsizma [The World of Islamic Mysticism. Transl. from English by N.I. Prigarina and A.S. Rapoport. 2nd Ed.]. Moscow: Sadra.

TRImingam J. Spenger 1989: Sufiiskie ordeny v islame [The Sufi Orders in Islam. Transl. by A.A. Staviskaia, ed. and prefaced by O.F. Akimushkin]. Moscow: Nauka.

TuMANOVICH N.N. 1981: Opisanie persidskikh i tadzhikskikh rukopisei Instituta vostokovedeniia AN SSSR, vyp. 6: Fol'klor (Zanimatel'nye rasskazy i povesti) [Description of the Persian and Tadzhik Manuscripts Kept in the Institute of Oriental Studies of the Academy of Sciences, USSR. Issue 6: Folklore (Entertaining Stories and Tales)]. Moscow: Nauka.

ĠolāM-HOSAYN YŪSOFī 1990: “Calligraphy”. In: Encyclopaedia Iranica, ed. by Ehsan Yarshater, vol. IV, fasc. 7. London and New York: Routlege \& Kegan Paul, 680-718. 